\title{
Anticipation in entrepreneurship
}

\author{
Prepublication version of chapter accepted for publication on Feb \\ $13^{\text {th }} 2019$ in Poli, R. (Ed) (2019) The Handbook of Anticipation. \\ Springer International AG, Cham. https://doi.org/10.1007/978-3-319- \\ $\underline{31737-3}$
}

\section{Ted Fuller}

\begin{abstract}
Entrepreneurship is a forward looking activity that embodies implicit imaginaries. If we remove the notion of a future from the field of entrepreneurship, field would cease to exist as its whole rationale is prospective. Entrepreneurship creates future value (Schumpeter 1934) through creative destruction; in uncertain contexts (Knight 1923) and with 'alertness' to opportunity (Kirzner 1982). Entrepreneurial opportunity embraces anticipation as imaginative reason, strategically employed and motivated by aspiration. Entrepreneurial effectuation is concerned with the controllable aspects of an unpredictable future. Entrepreneuring is a process (Steyaert 2007) producing ontological emergence. Entrepreneurship is expressed in action and produces change. Nadin observes that anticipation relates to the perception of change (Nadin 2010) and is always expressed in action (Nadin 2015). Entrepreneurial identity is significant and the models embodied in an anticipatory system are what comprise its individuality; what distinguish it uniquely from other systems. A change in these models is a change of identity (Rosen et al. 2012, p370). Entrepreneurship is relational and is coupled with other actors in the environment, generating a sense of shared anticipation, or anticipatory coupling. Anticipatory coupling as a social phenomenon seems ripe for further research. Being emplaced, entrepreneuring practice involve sensing and anticipa-
\end{abstract}


tion (Antonacopoulou and Fuller 2019). Although anticipation is a natural activity, the effectiveness of anticipation can be improved through greater awareness in each of these sets of processes, amongst others. We suggest that the dynamics of emergence require anticipations of multiple forms of value. Seeing entrepreneurship from an anticipatory standpoint brings more to the fore the nature of values in practice. Further research can help reveal the anticipatory work is done in entrepreneurship to maintain the anticipatory capacity of the enterprise and of the interdependent relationships that maintain the enterprise?

Keywords:

Entrepreneurship; Anticipation, Foresight, Emplacement, Anticipatory Work, Emergence

\section{Introduction}

This chapter considers the nature of anticipation as represented in the disciplinary field of entrepreneurship. Dominant theories are described in terms of their relationship to anticipation. The chapter then reflects on the research of the author and colleagues with respect to foresight and entrepreneurship, and more recently the nature of anticipation is entrepreneurial practice.

Overall, entrepreneurship is portrayed as a forward looking activity that embodies implicit imaginaries. These are powerful in explaining the character of entrepreneurship. The main grounding theories considered are the Schumpeterian (1934) conception of entrepreneurship as creating value for the economy through creative destruction; the role of entrepreneurship in uncertainty as portrayed by Frank Knight (1923); and the 'alertness' to opportunity identified by Israel Kirzner (1985). More modern conceptions are then described, being mainly Shane and Venkataraman (2000) definitional focus on opportunities discovery, evaluation and exploitation and Sara Sarasvathy's (2001) effectuation theory. Both of these theories explain entrepreneurship through models that link the 
future with the present, albeit in quite different ways. They are both oriented towards process, and so further work that has expanded process theories of entrepreneurship, with an orientation to identity and becoming is then described, (e.g. (Steyaert 2007). These approaches have also considered temporality as contextually significant and recognise the emergent nature of new venture generation, which involves ongoing learning and adaptation.

Research on entrepreneurial foresight is reported that illustrates ways in which the emergence of new ventures is more of an act of social foresight than relying on cognitive foresight for its direction. However, within the processes involved, there is evidence of probing the environment through experimental activities to improve the effectiveness of the enterprise; in anticipation of future value. It is also the case that in the creation of ventures, anticipatory narratives are used to stabilise the dynamic shaping of the enterprise in uncertain environments.

The centrality of anticipation to the everyday practices of entrepreneurship is further described by reference to recent work on emplacement, which is conceptualised as a relational space wherein the entrepreneur engages with the environment through practice, sensation and anticipation.

Finally some suggestions are made as to the contribution that anticipation may make to understanding entrepreneurship and also how studies of entrepreneurship might enhance our understanding of anticipation.

\section{The implicit nature of anticipation in mainstream entrepreneurship theories}

\section{Creative destruction}

Entrepreneurship as a scholarly field offers many theories with regard to the observed practices of establishing and developing innovative enter- 
prises. It is not necessary to catalogue all in order to demonstrate that in general the field has an anticipatory stance, even if, in the main, anticipation is not recognised explicitly in these theories. In particular, the relationship between entrepreneurship and emergence seems significant, and hence the role of anticipation in explanations of ontological emergence. Entrepreneurship is associated with the creation of 'new' (new products, new services, new enterprises, new institutions) and therefore the practice of entrepreneurship involves changing the status quo. The question is in what ways is anticipation apparent or manifest in such changes and in the emergence of new patterns of behaviour related to such change.

It is common for entrepreneurship as a field of study to turn to the theories of Joseph Schumpeter on creative destruction. Entrepreneurial action results in novelty, where old patterns are broken, and new combinations initiated that change dominant patterns of behaviour over time. Schumpeter's perspective was broadly economic, although highly aware of social consequences. Schumpeter argued that economic development occurred when 'new combinations' appear discontinuously (such as new products, processes, services, markets, industry structures). No doubt 'business model' would have been included if it existed in the lexicon of the day. As Bull and Willard (1993) report, Schumpeter asserted that the carrying out of new combinations is called 'enterprise', and the person whose function it is to carry these out is the 'entrepreneur'. He saw this person (i.e. an individualistic view) as a leader and contributor to the process of creative destruction. The question of profit making was less strong in Schumpeter's view than other theorists (such as Kirzner), but the idea of 'value creation' was at the heart of the Schumpeterian view of entrepreneurship. Entrepreneurial profit was "an expression of the value of what the entrepreneur contributes to production. [ ...] it attaches to the creation of new things, to the realization of the future value system...". (Schumpeter 1934 p153-154). Such profits could not be calculated, as they would take place at some point in the future. And with respect to 'the future' Schumpeter offers an insight into the entrepreneur's capacity to reconceptualise present day orders of things (or structures, or norms) which is "the capacity of seeing things in a way which afterwards proves to be true, even if it cannot be established at the moment" 
(Schumpeter 1934, p85). As Lawrence White put it, the entrepreneur's plans must be based on expectations, and these must be created by him (sic): an image of future markets is available not through sight but through insight" (White 1990, p93). I would put that as foresight as much as insight, but it is in the reconceptualising or reframing of 'combinations' in the present that give rise to future imaginaries.

This theory has resonance with Knight's explanation for entrepreneurial profit. In delineating risk from uncertainty, Knight observed that risk is measurable, based on prior evidence and thus insurable and that perfect competition leads to no profit beyond normal costs. In situations of risk therefore, where outcomes are predictable (albeit in a probabilistic sense) "no losses and no chance to make profits will arise out of [these circumstance]" (Knight 1923, s. I. II.26). Entrepreneurial profits arise in conditions that are unforeseen (and hence do not facilitate perfect competition). In such conditions [entrepreneurs] act upon estimates rather than [calculated] inferences, upon [...] intuition not reasoning, for the most part" (III.VII.36). From Knights perspective, prediction is not part of the explanation for entrepreneurial success.

A second aspect of Schumpeter's characterising observed entrepreneurship was that it created value as a result of the creative destruction. Through creative destruction entrepreneurship constituted economic development and greater wealth or value. This position may appear asymmetric because many entrepreneurial endeavours fail to create value and some destroy value through expending resources to expropriate wealth (Baumol 1996). However, it does characterise the overall macro effect of entrepreneurship on the economy when he was observing it. As Bull and Willard (1993, p190) observe , KIrzner (1985) was more specific in theorising 'value' in terms of perceiving profit opportunities and initiating actions to create this, mainly by fulfilling unsatisfied needs or improving efficiencies. The entrepreneur was (is) "alert" (p7) to such opportunities, and presumably motivated by them. This alertness is a "speculative ability to see into the future" (p7) seeking gains and "acting in the light of the future as [the entrepreneur] envisages it..." (p55). Later research shows 'alertness' (scanning, search and evaluation) to be a mediator in small business success (Amato et al. 2017). We will return to notions of 'value' later. 


\section{Opportunity}

Opportunity (to create value or profit) has become a trope in entrepreneurship literature, forming the basis of simple forms of process theory. The most cited article in entrepreneurship in the ten years following its publication was by Shane and Venkataraman (2000) which 'defined' the field of entrepreneurship as "the scholarly examination of how, by whom, and with what effects opportunities to create future goods and services are discovered, evaluated, and exploited". This definition identified a 'nexus' between the entrepreneurial individual and the 'opportunity' that was external to the individual, i.e. contextual, and in much the forms described by Schumpeter. To study entrepreneurship (and therefore to understand what it is) should, they said, be to study "sources of opportunity and processes of discovery, evaluation and exploitation". Thus at a simple level, one could reasonably argue that opportunity seeking and evaluation are forward looking or anticipatory processes. Also, that acting upon perceived opportunity is synonymous with effecting action in an anticipatory system.

A 2010 reflection on the literature citing this work illustrates numerous authors offering their particular interpretation of 'opportunity' and related processes. Some 40 conceptual and 28 empirical efforts were analysed. The authors (Short et al. 2009) conclude that this literature "calls attention to three main issues: the discovery versus the creation of opportunities, temporal dynamics surrounding opportunities, and the evolution of ideas and dreams into opportunities." (p55). From an anticipatory studies perspective, these topics relate to i) modelling relations between the anticipatory system and its environment, and hence what is recognised as a need to act; ii) the way in which the future is manifest in the temporality (although in the main temporal dynamics speaks more to the evolutionary development process than the relationship with the future and iii) ontological expansion (Tuomi 2018) as a result of creative and learning activities.

Also raised in this literature is the question of what constitutes an entrepreneurial entity, i.e. who or what is it that has agency in making an opportunity. Historically the identity of the entrepreneur was essentially individualistic. While this remains largely so, recognition is given to social 
relational processes in which entrepreneurship is embedded (sometimes said to mediate the nature of opportunity and opportunity taking), e.g. (Dimov 2007) and also more simply to entrepreneurial partnerships and teams of people. Davidson (Davidsson 2015) uses the term 'Actor' as a covering term for the entrepreneurial entity.

It is interesting that in the Short et al. 2009 study the term "anticipation" does not appear. However, their analysis offers some sense of anticipatory activity reflected in the literature. For example, Gaglio (2004) on the use of counterfactuals, Chiles et al (2007) on creative imagination, Fiet (Fiet 2007; Fiet et al. 2013) on the use of systematic search, Baron (2008) on the recognition of the power of affect (which is anticipatory), Jennings (1990) on the use of prospector strategies, Wiklund and Shepherd (2003) noting that aspiration is important to grow and Mullins and Forlani (2005) showing that opportunity taking is related to the (perceived) likelihood of loss/gain, i.e. is anticipatory. The term anticipation also does not appear in the paper published five years later by Davidsson (2015) seeking to 'reconceptualise' entrepreneurial opportunities. Davidsson uses the term "prospective" and relates this to favourable outcomes for a new venture in the making. He suggests that 'opportunities' be given firmer constructs, citing as candidates: specific changes in the environment, "imagined future ventures" and the actors subjective evaluation of the stimulus for activity. In other words, anticipatory scanning and evaluation. In short the flavour of the literature on opportunity embraces anticipation as imaginative reason, strategically employed and motivated by aspiration.

\section{Effectuation}

A further now well-established concept in entrepreneurship literature is "effectuation". The term may resonate with those familiar with Rosen's Anticipatory Systems as his model contained an 'effector' which is the power of the system to alter its state or the state of inputs to the system. Within entrepreneurship, the term was coined by Sara Sarasvathy on the basis of her empirical research with entrepreneurs. She deduced that in related to simple models of cause and effect, entrepreneurs did not explicitly apply theories of causation in their reasoning and practice. What 
they did, she said, was to use effectual reasoning rather than causal reasoning. Effectual was thus coined as an inversion of 'causal'. By causal, she was referring to 'predictive reasoning' (she was critical of MBA approaches to teaching entrepreneurship). Predictive reasoning starts from end-point goals which strategy is then designed to achieve. She did not find evidence of such approaches amongst successful entrepreneurs. Effectual reasoning she suggested started with given means from which possible new 'ends' were imagined. She published the work in 2001 (Sarasvathy 2001) and has built a strong follow-up practitioner literature since then. The futures orientation of this concept is clear. One of the principles of Sarasvathy's effectuation is that the future cannot be predicted but entrepreneurs can control some of the factors which determine the future, in other words, they have agency, but the 'ends' are unanticipated (Sarasvathy 2008, p38). Effectuation reflects dynamic nonlinear and ecological environments and on the controllable aspects of an unpredictable future. What is done depends on the individual actor, their levels of acceptable risk and resources, including alliances and networks of cooperation (Sarasvathy 2001 p251).

\section{Process theories - entrepreneuring}

Over the last twenty years the literature in entrepreneurship has been considerably enriched by a greater focus on process and practice which perhaps illuminate some of Saravathy's observations further, and give insights into ways in which 'opportunities' are constructed and enacted. Such research is concerned less with the economic or psychological dimensions of entrepreneurship and more with the social and anthropological aspects. The research is wide ranging, but tends to encompass greater relationality than the earlier individualistic research arising from Schumpeter and economic rational theories. A good starting point for exploring entrepreneurship process and its relationship to anticipation is Chris Steyaert's notion of 'entrepreneuring'. Entrepreneuring is Steyaert's "process theory of entrepreneurship" (Steyaert 2007) incorporating ontological emergence (or 'becoming'). In his review of entrepreneurship process literature, Steyaert notes that "the creative process 
view to which all [the approaches reviewed] subscribe engenders a fundamental rupture with mainstream approaches that conceive of entrepreneurship as being located in a stable world, that work with a logic of causation and that, consequently, emphasize entrepreneurial activities as a kind of allocation or discovery" (2007, p470). Instead, entrepreneuring can be considered as ways that uncertainty, risk and opportunity are experienced in daily life. In such an experiential space possibilities are formed moment by moment (Fletcher and Selden 2016), a point drawn from Emirbayer and Mische notion of agency as "a temporally embedded process of social engagement, informed by the past but also oriented towards the future as a 'projective capacity' [...] within the contingencies of the moment" (Emirbayer and Mische 1998, p962). Time, they argue is constituted through emergent events, which require the [human consciousness] to have the capacity to be both temporally and relationally in a variety of systems at once (p968). Entrepreneurship, with its sense of freedom to act within contexts, between contexts and (as shown later) its generation of emergence, offers a strong example of agency.

With (entrepreneurial) agency comes reflexive entrepreneurial identity. Identity is shaped and reshaped through time and via identity work. Identity is an important aspect of a "natural system that contains an internal predictive model of itself and of its environment" (Rosen 1985, p13). Whether identity is a 'predictive' model in itself is an open question, but from a human perspective, self-identity is clearly part of the model of oneself and, as such, frames the interpretation of the meaning of events or 'inputs' from the environment and the actions arising from these experiences. Rosen commented that "[We] might even say that the models embodied in an anticipatory system are what comprise its individuality; what distinguish it uniquely from other systems. As we have seen, a change in these models is a change of identity..." (Rosen et al. 2012, p370). In as much as (business) strategy is anticipatory (and it should be, otherwise how can it be a strategy?), Stacy (2003) argues that the evolving patterns of an organisation's identity (the entrepreneurial firm in this case) is [its] strategy. The literature on entrepreneurial identity relates more to identity work in the doing of entrepreneurship. For example, Lounsbury and Glynn (2001) describe the story telling associated with the crafting of new ventures by entrepreneurs as they gather capital re- 
sources, Downing (2005) identifies narrative and dramatic, emotional, processes in the co-production of entrepreneurial organisation identity, Bruni et al (2004) illustrate processes of symbolic construction of gender and entrepreneurship and Down (2006) illustrates ways in which entrepreneurial self-identity is formed. These examples and many more reflect the dynamism of entrepreneurial identity, as a living, evolving and performative power with respect to what the entrepreneur does and how the venture is formed. It is thus in the sense of a 'living entity' that I assert the relationship between anticipatory systems and entrepreneurship. The narratives and discourses with various stakeholders in doing identity work are examples of the ways that these particular anticipatory systems link to their environment. The dynamics of these links or coupling is to generate a sense of shared anticipation, or anticipatory coupling. Anticipatory coupling as a social phenomenon seems ripe for further research.

The nature of entrepreneurial work and identity is explicitly futureorientated. An example of this is in the writing of Flores and Gray (2000, p32)

"The entrepreneur assumes a defining commitment to develop an ignored practice that will resolve a disharmony on a small or large scale. [and] in declaration of responsibility for a certain resolution of communal disharmony, they become authors of a continuous life story".

In other words, in this account, the entrepreneur has clear intent and a core identity or purpose and hence will evaluate dynamic situations through that perspective.

Such a clear intent and identity is not unchangeable - the process is reflexive and learning is manifest (e.g. learning what works and doesn't work; how the environment is changing, how other agents are behaving, and etc.) Some theories of entrepreneurship take a 'learning' as central to understanding what distinguishes entrepreneurship. Apart from opportunity', possibly the most recognisable trope in entrepreneurship literature is failure, and learning from failure. As Cope identified in an empirical study of failed ventures, "knowing what can go wrong' is an invaluable asset that can enable more considered, anticipatory and affirmative future actions" (Cope 2011, p612). From his evidence, Cope proposed that 'restoration-oriented dynamics' (Shepherd 2009) was important in fostering emancipatory learning outcomes. The resulting addi- 
tions to the entrepreneur's 'stock of experience' (Reuber and Fischer 1999) that Cope proposes is, in effect, an adaptation of the anticipatory system's modelling relations. Although Cope accepts that failure can be a set-back, "far from constraining future actions [...] learning outcomes ( $p$ 616) can substantially improve levels of entrepreneurial preparedness for subsequent entrepreneurial activity" ( $p$ 618). As one of his interviewees (whose venture had failed) reportedly said (p617):

"I know a lot more about the things that you don't do. A lot more about the warning flags to see when the communications break down and all of us I think have learned how to handle intense daily pressure better...how to work out what the warning signs are, how to communicate the warning signs so you can correct them before you go too far down the road is a very valuable lesson I think for all of us".

This specific example can be generalised in terms of being more able to identify opportunities as a result of learning from failure, building a clearer set of rules or protocols (or models) from which to evaluate future possibilities. Mueller and Shepherd (2016) illustrate this through the use of so called expert protocols as an analytical frame in assessing entrepreneurs evaluation of particular scenarios. They found a positive relationship between the experience of previous business failure and the range of protocols used by the entrepreneurs - in simple terms, the greater the experience of failure the wider the range of evaluation protocols used.

The ability to learn from negative outcomes in more corporate entrepreneurial settings was identified by Bingham and Kahl (2014) who offer a typology of anticipatory learning, and position it as a primary type of organizational learning. Anticipatory learning (from an anticipation of negative outcomes), they say, can be informed by user concerns, outside reactions or self-detection.

It would appear from the above that anticipation is inherent in entrepreneurship. Not least by its definitional properties of creating value and creative destruction, entrepreneurship is expressed in action and produces change. Nadin observes that anticipation relates to the perception of change (Nadin 2010) and is always expressed in action (Nadin 2015). 


\section{Anticipation in entrepreneurial processes}

For many years colleagues and I have investigated the relationships that entrepreneurs have with the futures, i.e. what the nature of their foresight is, if any. The quest was driven by experience of working with entrepreneurs in training courses and with empirical qualitative studies of small groups and single case studies. Working in the 1990's with small business owners and professional advisers, we attempted to teach the skills of scenario planning to assist the 'strategic awareness' (Gibb and Scott 1985) of the business leaders. Perhaps we were bad trainers, but we found it difficult if not impossible to generate the motivation among the group for such activity. They were keen to learn how to manage the growth of their enterprises, but didn't see the value in scenario planning. To them the environment was too uncertain for the comfortable frameworks of 'intuitive' logics (van de Heijden et al. 2002; Schwartz 1991). The idea of anything 'long term' was just not part of their mental model. This is not to say they didn't have ambitions or dreams, but 'planning' in uncertain times was not done in the rational way of scenarios. One insight from considering further their relationship with the future, in the context of agents in complex systems, led me to understand that entrepreneurs act as probes into the future for society and the economy. Each agent is undertaking their business creation with the hope and belief of success. Many fail. Those who succeed, in a small way or on a large scale, are creating the future for many other people. Those who fail have temporarily created a future that is not sustainable. This led us to suggesting that in some economic and social contexts entrepreneurship is foresight, it has a role of social foresight (Fuller and Warren 2006).

This position begged the question of how entrepreneurs enacted this foresight role as an integral part of being entrepreneurial. Given the significance of uncertainty of entrepreneurship, we investigated this question in an empirically grounded approach dealing with the particularities of specific cases, but from a general methodological stance of ontological emergence. We took an empirically grounded approach, i.e. the foresight involved (or anticipation involved) was situation dependent. We were concerned with processes and structures that linked the entrepreneur, their enterprise and the wider environment. Given the definitional nature 
of innovation within entrepreneurship theory (creative destruction), we theorised that the creation of the 'new', such as new ventures or new practices involved the emergence of those practices from some preexisting state but as 'new combinations' as Schumpeter put it.

With respect to anticipation, we theorised from our studies a model that categorised four integrated sets of processes detectable in the practices of entrepreneurship. These gave rise to emergent (new) entities, some of which persisted. The four broad sets of processes we called Experiments, Reflexive identity formation, Organising domains and Sensitivity to conditions.

Experimental behaviour, which includes trial and error, improvisation and adaptation, seems to be essential for entrepreneurship practice. Baum (2003) suggests that experimentation is important where rapid change is needed and information is poor (i.e. uncertainty). Baum found that empirically the greater the use of experimentation, the greater the incidence of promising venture start-up, quoting, amongst others, Stevenson on the value of experiments. Stevenson (1983) identified the value of experiments for conserving entrepreneurs' limited resources: "The entrepreneur's revolutionary manner of commitment allows for the management of risk, since the ability to decommit quickly must accompany the ability to commit quickly [...] with the capacity to decommit, an entrepreneur is able to engage in experiments" (p41). We found entrepreneurial experimentation of the form 'let's try it to see what works' which provided experiential situated learning. Experiments in the form of new projects also involved collaborations with external but close stakeholders or partners, which helped the entrepreneur to anticipate the needs of these stakeholders, or even create demand through the developmental collaboration (Fuller et al. 2008, p9).

The significance of reflexive identity formation is discussed above. What we observe in empirical studies is a duality of identity work. The identity of the founders of the venture can change over time with regards to that venture, and the identity of the venture can change with respect to its environment. Strong core identity (e.g. of being entrepreneurial, or being a leader in a particular industry for example) maintains a direction and a framework from which to evaluate changes in the environment or in the 
entity, or the self. Modifying the identity dynamically is how the enterprise remains meaningful, relevant and connected to its clients, stakeholders and markets. Such modifications may require changes to the 'business model', the narratives, and the everyday practices. These are the signs of the enterprise as being a living anticipatory entity.

In our research we further note that dynamic changes to the 'organising domain' of the enterprise are evident in the processes by which novelty emerges. We use 'organising domain' as a label for the actual set of practices, normal procedure, expectations etc. that constitute the institutional or structural aspects of the enterprise, i.e. what it does and how it does it. Lichtenstein (2000) shows how in each of four high technology business start-ups the business model had to be changed several times before becoming stable, not because a particular pattern was unstable per se, but because it was designed relative to an unstable and unpredictable environment. The reshaped behaviour pattern of the enterprise is, according to Lichtenstein, an "emergence from a process of self-organizing" that created repeating and amplified behaviours around the dominant logic. We equate this process with the effector and action aspects of anticipatory systems, and indeed of anticipation. The entity acts in a way that is consistent with its model of itself in its environment and amends that action through experience, anticipating what 'will work' in the iterative generation of a more stable and effective way of acting.

The fourth set of processes in the creation of emergent properties from entrepreneurial activity relate to what we termed 'sensitivity to conditions' - the agent's propensity to reshape their relationship with the salient actors (Fuller et al. 2008, p12). This can be seen as the effectiveness of the anticipatory systems coupling with the environment. We noted two aspects, (a) the threshold of unplanned change (internal or external to the firm) that triggers a reorganisation of activities (b) the timing of the instigation of changes. The first of these is the capability to detect difference. The second aspect concerns the relative imperative (motivation or incentive) to change, which we suggest may account for the threshold at which change is triggered and the rate at which it takes place.

Our conclusion was that each of the above four sets of processes is discernible to the actor, is manageable and is an area in which competence 
can be developed. In other words, although anticipation is a natural activity, the effectiveness of anticipation can be improved through greater awareness in each of these sets of processes, amongst others.

\section{Value}

As explained above, value creation is a central part of understanding the role of entrepreneurship. It is reasonable to assume that the expectation of future value creation is an important source of energy or motivation for the processes and practices of entrepreneurship. In a study of emerging projects in the creative industries we (Fuller et al. 2011) identified that the anticipation of value was inherent in the observed practices of the project teams. However, what was taken as 'value', and what motivated some of the actors involved went well beyond the pursuit of economic wealth.

As we reported, a range of areas of anticipated value sustained the dynamics of the venture creation. These included technical solutions to problems, artistic experiences, reputations, fun and public credibility. That is, a mix of human, social and cultural capitals that were as powerful as the anticipation of economic rents in sustaining the dynamics of the cases we observed. We suggested that the dynamics of emergence in creative industries require anticipations of multiple forms of value, which have meaning at multiple levels, e.g. individual, organizational and sector. "The nature of the values anticipated guides sensitivity to environment, organizing domains, reflexive identity and the emergent evaluation and purpose of experimental practice" (Fuller et al. 2011, p92). As explained elsewhere in this Handbook (Fuller 2018), from a critical realist perspective, anticipation is a causal mechanism, and that (the entrepreneur's) disposition to act on anticipation is causal - it motivates action towards the creation of future value. 


\section{Emplacement: practice, sensing, and anticipation}

To investigate in greater depth the role of anticipation in entrepreneurship, Antonacopoulou and Fuller (2019) have considered its role in everyday practice and lived experience. The work contributes to both anticipation studies and Entrepreneurship as Practice, which is drawn from social practice theory. Social practice theory asserts that our knowledge is mediated through our understanding of events and interactions with people. (Schatzki et al. 2001) In the case of entrepreneurship the cause of the emergent venture is within the practices themselves, and not that practices are simply an output of some other cause. Johannisson (2011) conceptualised entrepreneurship practice taking place in an 'organising context' which frames 'enactive space'. The enactive space involves emotional energy and embodied practices. We have suggested that practice theory concepts such as enacting and embodiment can be extended by considering how entrepreneurship is emplaced. Emplacement brings a greater sense of relationality and temporality than enacting and embodiment, accounting for duration and the seizing of moments which define entrepreneurial action as part of everyday connectedness.

Emplacement recognises the competing/performing body as part of an ecology of things in progress offers a series of analytical advantages. It locates the performing/competing body within a wider ecology, allowing us to see it as an organism in relation to other organisms and its representations in relation to other representations. (Pink 2011, p354)

Pink's description of emplacement appears to show similarities to an anticipatory system, having a sense of living dynamics and of coupling with its environment. The temporality of emplacement; "knowing as we go, not before we go" (Ingold 2000, p229), reflects entrepreneurship s taking place in a space where possibilities are formed moment by moment as Fletcher and Selden (2016) put it, after Emirbayer and Mische (1998), while investigating connections between a relational conceptualisation of context and real time emergence. They assert, that "entrepreneurs adjust their relationships with multiple contexts in real-time under conditions of genuine uncertainty".

Antonacopoulou and Fuller (2019, Table 1) suggest that emplacement is "the dynamic placement reflecting the choices that guide actions to realise what matters to social actors as they navigate the [volatile, uncertain, 
complex, ambiguous] ecosystems they contribute in co-creating. [...] It draws on practising, sensing and anticipating to drive the position of actions such that their impact is realised."

How then are inferential entailments formed to link anticipation with actions in highly uncertain environments? Pink suggests Wacquant's (2004, p467) idea that "all agents are embodied and all social life rests on a bedrock of visceral know-how, or pre-discursive knowledges and skills that are both acquired and deployed in practical entailment with a definite social cosmos".

How are such knowledges and skills (and hence anticipatory inferences) embodied? Downey (2007, p223) asks "what kinds of biological changes might occur when learning a skill?" This question seems consistent with Rosen's theory that it is the (predictive) modelling relations that change the organism's [practical] entailments, which may be at the biological lev$\mathrm{el}$, and hence effect changes in practices.

As Antonacopoulou and Fuller (2019) point out, emplacement in practising entrepreneurship draws attention to the modes of anticipatory coupling of the actors. "Such couplings are central organising features of perception, cognition, affect, memory, motivation and action which may be conscious prospection occurring spontaneously and continuously (Seligman et al. 2013). These points reinforce why practising entrepreneuring fuels anticipation, creating possibilities, reflexively appraising them at the same time, providing a form of foresight."

\section{How does anticipation change our understanding of entrepreneurship?}

Entrepreneurship is conceptually formulated as a forward looking activity and is an activity that creates new patterns and processes. Entrepreneurship is agential activity that can change social structures. The dominant explanation of entrepreneurship is its placement in the present, being enacted moment by moment, with narrative histories as evidence of identity work. The question of whether entrepreneurship is goal directed or 
more effectually emergent remains open and likely to be situation dependent. Entrepreneurship is associated with risk, or more properly with acting in uncertain situations. The entrepreneurship literature is silent on the nature of salient imaginaries, which says something of the disciplinary paradigm used in entrepreneurship research. Reducing imaginaries to a flat notion of value creation or opportunity seems to remove the explanatory insights that might be revealed by a greater understanding of the power of anticipation as a guiding and motivating process that mediates resources and practices.

What if we remove the notion of a future from the field of entrepreneurship? Arguably the field would cease to exist as its whole rationale is prospective. As with many disciplinary areas, if we change the conception of causal knowledge and related action as being anticipatory, then we start to ask different research question. We also need to look at the practices and narratives of entrepreneurs from that perspective. Central to this, from the perspective of anticipatory systems theory, is the nature of inferential models in use (whether cognitive or embodied) and the ways in which these are modified.

Seeing entrepreneurship from an anticipatory standpoint also brings more to the fore the nature of values in practice. If entrepreneurial actions are based on anticipatory inferences, what role do values play in the inferential process, and what values are they? As individuality and related entrepreneurship is such a powerful force in modern society, values as practiced make big differences to the future. The key point here is that from an anticipatory perspective, inferential evaluation makes a real difference to the way entrepreneurs construct their relationship with their world of stakeholders, and hence to what they do.

\section{How does entrepreneurship change our understanding of anticipation?}

As an example of effective agency, entrepreneurship - with its use of (unlabelled) imaginaries, such as opportunity, value creation or creative destruction, confirms the power of anticipation in everyday entrepreneurial 
practices. Future empirical research in this particular field will yield further insights into the nature of anticipatory social systems. Entrepreneurship is constructed at multiple levels and requires legitimisation at those levels. Individuals exert agency; institutions (financial systems regulations) facilitate entrepreneurship; entrepreneurship is central to competition and dynamic markets (as is anticipation); social structures are needed for entrepreneurship to exist. Entrepreneurship is at once individual and relational. To simplify the entrepreneur or entrepreneurial enterprise (whether for profit or with some other purpose) as an anticipatory system, fails to accommodate the multiplicity of anticipatory systems necessary for entrepreneurship to occur. Anticipatory social systems, as a class of social systems appear to be multiplex. Perhaps all social systems are anticipatory, and it is the anticipation that adds complexity through feedforward as well as feedback.

If entrepreneurship is an example of a socio-economic activity riven with anticipation, imagination and aspiration as cultural facts (Appadurai 2013), then what are the everyday anticipatory activities? Further research can help reveal the anticipatory work is done in entrepreneurship to maintain the anticipatory capacity of the enterprise and of the interdependent relationships that maintain the enterprise? This is not simple cognitive scenario analysis. It seems from the above that anticipatory capacity is insinuated in the very nature of entrepreneurial practice.

The nature of entrepreneurship may not change our understanding of the basic premise of anticipation, but it does offer empirical settings and contexts for the study and enrichment of anticipation in its many forms.

\section{References}

Amato C, Baron RA, Barbieri B, Bélanger JJ, Pierro A (2017) Regulatory Modes and Entrepreneurship: The Mediational Role of Alertness in Small Business Success. Journal of Small Business Management 55:27-42. doi:10.1111/jsbm.12255

Antonacopoulou EP, Fuller T (2019) Practising Entrepreneuring as Emplacement: The Impact of Sensation and Anticipation in 
Entrepreneurial Action. Entrepreneurship and Regional Development In Print

Appadurai A (2013) The Future as cultural fact: essays on the global condition. New York : Verso Books, London ;

Baron RA (2008) The role of affect in the entrepreneurial process. Academy of Management Review 33 (2):328-340. doi:10.5465/AMR.2008.31193166

Baum JAC Entrepreneurs' start-up cognitions and behaviors: dreams, surprises, shortages, and fast zigzags. In: Frontiers of Entrepreneurship Research, Glasgow, UK, 2003. Babson College,

Baumol WJ (1996) Entrepreneurship: Productive, unproductive, and destructive. Journal of Business Venturing 11 (1):3-22. doi:10.1016/0883-9026(94)00014-X

Bingham CB, Kahl S (2014) Anticipatory Learning. Strategic Entrepreneurship Journal 8 (2):101-127. doi:10.1002/sej.1166

Bruni A, Gherardi S, Poggio B (2004) Doing gender, doing entrepreneurship: An ethnographic account of intertwined practices. Gender, Work and Organization 11 (4):406-429. doi:10.1111/j.1468-0432.2004.00240.x

Bull I, Willard GE (1993) Towards a theory of entrepreneurship. Journal of Business Venturing 8 (3):183-195. doi:10.1016/08839026(93)90026-2

Chiles TH, Bluedorn AC, Gupta VK (2007) Beyond Creative Destruction and Entrepreneurial Discovery: A Radical Austrian Approach to Entrepreneurship. Organization Studies 28 (4):467

Cope J (2011) Entrepreneurial learning from failure: An interpretative phenomenological analysis. Journal of Business Venturing 26 (6):604-623. doi:10.1016/j.jbusvent.2010.06.002

Davidsson P (2015) Entrepreneurial opportunities and the entrepreneurship nexus: A re-conceptualization. Journal of Business Venturing 30 (5):674-695. doi:10.1016/j.jbusvent.2015.01.002

Dimov D (2007) Beyond the single-person, single-insight attribution in understanding entrepreneurial opportunities. Entrepreneurship: Theory and Practice 31 (5):713-731. doi:10.1111/j.15406520.2007.00196.x

Down S (2006) Narratives of enterprise : crafting entrepreneurial selfidentity in a small firm. Edward Elgar, Cheltenham

Downey G (2007) Seeing with a "Sideways Glance": visuomotor "knowing" and the plasticity of perception. In: Harris M (ed) 
Ways of knowing, new approaches in the anthropology of experience and learning. Berghahn, Oxford,

Downing S (2005) The Social Construction of Entrepreneurship: Narrative and Dramatic Processes in the Coproduction of Organizations and Identities. Entrepreneurship: Theory \& Practice 29 (2):185-204

Emirbayer M, Mische A (1998) What is Agency? American Journal of Sociology 103 (4):962

Fiet JO (2007) A prescriptive analysis of search and discovery. Journal of Management Studies 44 (4):592-611. doi:10.1111/j.14676486.2006.00671.x

Fiet JO, Norton Jr WI, Clouse VGH (2013) Search and discovery by repeatedly successful entrepreneurs. International Small Business Journal 31 (8):890-913. doi:10.1177/0266242612465690

Fletcher DE, Selden P (2016) A relational conceptualization of context and the real-time emergence of entrepreneurship processes. In: Welter F, Gartner WB (eds) A Research Agenda for Entrepreneurship and Context. Edward Elgar, Cheltenham, pp 7992. doi:10.4337/9781784716844

Flores F, Gray J (2000) Entrepreneurship and the wired life. Demos, London

Fuller T (2018) Anticipation and the Normative Stance. Handbook of Anticipation. Springer International AG, Cham. doi:https://doi.org/10.1007/978-3-319-31737-3

Fuller T, Warren L (2006) Entrepreneurship as foresight: A complex social network perspective on organisational foresight. Futures, Journal of Policy, Planning and Futures Studies 38 (8)

Fuller T, Warren L, Argyle P (2008) Sustaining entrepreneurial business: A complexity perspective on processes that produce emergent practice. International Entrepreneurship and Management Journal 4 (1):1-17. doi:10.1007/s11365-007-0047-y

Fuller T, Warren L, Norman S-J (2011) Creative methodologies for understanding a creative industry. In: Henry $\mathrm{C}$, deBruin $\mathrm{A}$ (eds) Entrepreneurship and the Creative Economy: Process, Policy and Practice. Edward Elgar,

Gaglio CM (2004) The role of mental simulations and counterfactual thinking in the opportunity identification process. Entrepreneurship: Theory and Practice 28 (6):533-552. doi:10.1111/j.1540-6520.2004.00063.x 
Gibb AA, Scott MG (1985) Strategic Awareness, Personal Commitment and the Process of Planning in the Small Business. Journal of Management Studies 22 (6):597-625.

Ingold T (2000) The perception of the environment : essays on livelihood, dwelling and skill. Routledge, London

Jennings DF, Seaman SL (1990) Aggressiveness of response to new business opportunities following deregulation: An empirical study of established financial firms. Journal of Business Venturing 5 (3):177-189. doi:10.1016/0883-9026(90)90031-N

Johannisson B (2011) Towards a practice theory of entrepreneuring. Small Business Economics 36 (2):135-150

Kirzner IM (1982) The theory of entrepreneurship in economic growth. In: Kent CA, Sexton DL, Vesper KH (eds) Encylopedia of Entrepreneurship. Printice Hall, Engelwood Cliffs, NJ,

Kirzner IM (1985) Discovery and the capitalist process. University of Chicago Press, Chicago

Knight F (1923) The Ethics of Competition. Quarterly Journal of Economics 37:579-624. Reprinted in The Ethics of Competition; and Selected Essays, vol. 571

Lichtenstein BB (2000) Emergence as a process of self-organizing - New assumptions and insights from the study of non-linear dynamic systems. Journal of Organizational Change Management 13 (6):526-544

Lounsbury M, Glynn MA (2001) Cultural entrepreneurship: stories, legitimacy, and the acquisition of resources. Strategic Management Journal 22:545-564

Mueller BA, Shepherd DA (2016) Making the Most of Failure Experiences: Exploring the Relationship Between Business Failure and the Identification of Business Opportunities. Entrepreneurship: Theory and Practice 40 (3):457-487. doi:10.1111/etap.12116

Mullins JW, Forlani D (2005) Missing the boat or sinking the boat: A study of new venture decision making. Journal of Business Venturing 20 (1):47-69. doi:10.1016/j.jbusvent.2003.08.001

Nadin M (2010) Anticipation and dynamics: Rosen's anticipation in the perspective of time. International Journal of General Systems 39 (1):3-33. doi:10.1080/03081070903453685

Nadin M (2015) Concerning the knowledge domain of anticipation Awareness of early contributions in the context of defining the field. International Journal of General Systems 44 (6):621-630. doi:10.1080/03081079.2015.1032524 
Pink S (2011) From embodiment to emplacement: Re-thinking competing bodies, senses and spatialities. Sport, Education and Society 16

(3):343-355. doi:10.1080/13573322.2011.565965

Reuber AR, Fischer E (1999) Understanding the consequences of founders' experience. Journal of Small Business Management 37 (2):30-45

Rosen R (1985) Anticipatory systems : philosophical, mathematical and methodological foundations. International series on systems science and engineering ; v.1. Pergamon, Oxford

Rosen R, Rosen J, Kineman JJ, Nadin M (2012) Anticipatory systems : philosophical, mathematical, and methodological foundations. 2nd ed. edn. Springer, New York ; London

Sarasvathy SD (2001) Causation And Effectuation: Toward a theoretical shift from economic inevitability to entrepreneurial contingency. Academy of Management Review 26 (2):243-263

Sarasvathy SD (2008) Effectuation : elements of entrepreneurial expertise. New horizons in entrepreneurship. Edward Elgar, Cheltenham, Glos, UK ; Northampton, MA

Schatzki TR, Knorr-Cetina KD, Savigny Ev (2001) The practice turn in contemporary theory. Routledge, London

Schumpeter JA (1934) The Theory of Economic Development: An inquiry into Profits, Capital, Credit, Interest and the Business Cycle. Harvard University Press, Cambridge, Mass

Schwartz P (1991) The Art of the Long View. Doubleday, New York

Shane S, Venkataraman S (2000) The promise of entrepreneurship as a field of research. Academy of Management Review 25 (1):217226

Shepherd DA (2009) Grief recovery from the loss of a family business: A multi- and meso-level theory. Journal of Business Venturing 24 (1):81-97. doi:10.1016/j.jbusvent.2007.09.003

Short JC, Ketchen DJ, Shook CL, Ireland RD (2009) The Concept of "Opportunity" in Entrepreneurship Research: Past Accomplishments and Future Challenges. Journal of Management 36 (1):40-65. doi:10.1177/0149206309342746

Stacey RD (2003) Strategic Management and Organisational Dynamics, the Challenge of Complexity. 4th edn. FT prentice hall, London

Stevenson HH (1983) A New Paradigm for Entrepreneurial Management. In: Kao JJ, Stevenson HH (eds) Entrepreneurship: What it is and how to teach it. Harvard University Press. , Boston 
Steyaert C (2007) 'Entrepreneuring' as a conceptual attractor? A review of process theories in 20 years of entrepreneurship studies. Entrepreneurship \& Regional Development 19 (6):453-477. doi:10.1080/08985620701671759

Tuomi I (2018) Ontological Expansion. In: Poli R (ed) Handbook of Anticipation. Springer, Cham. doi:https://doi.org/10.1007/978-3319-31737-3 4-1

van de Heijden K, Burt G, Cairns G, Wright G (2002) The Sixth Sense; accelerating organisational learning with scenarios. John Wiley and Soncs Ltd, Chichester

Wacquant LD (2004) Body \& soul : notebooks of an apprentice boxer. Oxford University Press, Oxford ; New York

White LH (1990) Entrepreneurship, Imagination and the Question of Equilibration. In: Littlechild SC (ed) Austrian Economics, vol III. Edward Elgar, Brookfield, pp 87-105

Wiklund J, Shepherd D (2003) Aspiring for, and Achieving Growth: The Moderating Role of Resources and Opportunities. Journal of Management Studies 40 (8):1919-1941. doi:10.1046/j.14676486.2003.00406.x 